себе надежду на торжество человечности, доброты и милосердия, которые требуют и действенных нравственных усилий

Списо к испо льзо ва нно й лите ра туры :

1 А.П. Бабушкина. История русско й де тско й лите ра туры. - М.: Го с. уче б.-пе да го г. изд-во, 1948. $9 c$.

2 FactRetri ever.com | Interesting Facts for the Curious Mind. www.randomhi story.com.

3 А нто ло гия миро во й де тско й лите ра туры . - М.: А ва нта , 2009. - 509 с

4 Де тска я лите ра тура. - М.: А ка де мия, 2010. - 384 c.

5 Де тская лите ра тура Австрии, Германии, Шве йцарии. Учебная хрестома тия для начальной и сре дне й шко л. Ча сть 1. - М.: Вла дос, 2011. - 384 с

6 А нтипо ва И.А. Картина мира в образовательной литера туре XVIII в. Для детей // Детский сбо рник: Ста тьи по де тско й лите ра туре и а нтро по ло гии де тства . - М.: 2003. 147-154 c

7 Атарова К.Н. Секреты простоты // Даниель Дефо . Робинзо н Крузо. - М., 1990

8 Мура вье в В. Путе ше ствие с Гулливе ро м. (1699-1970). - М.: Книга , 1972. - 207 с

9 Бо йко С.П. Волшебная страна Пьера и Шарля Перро. М., 2002.

10 Цивьян Т.В. К семантике пространственных элементов в влшебной сказке // Типологические исследования по фольклору: Сб. ста тей. М., 1975

11 Шевченко Г.А. Предисловие // Братья Гримм / Г. Герстнер; Пер. с нем. Е.А. Шеншина. - М.: Молгвардия, 1980

12 Конева Е. А. Парадоксы сказочного творчества братье в Гримм // Молодой ученьй. - 2016. - №2

13 Бент М.И. Немецкая романтическая новелла. Генезис, эволющия, типология Текст. / М.И. Бент. Иркутск: Изда те льство Иркутско го униве рсите та, 1987. 119 с

14 Сухомлинский, В.А. Сердие отдаю детям / В. А. Сухомлинский. - 4-е изд. - Киев: “Радянська школа”, 1973. $-356 c$.

References:

1 A.P. Babuskina. Isto ria ruskoi de tsko i lite ra tury. - M.: Go s. uche b.-pe da go g. izd-vo, 1948. - 9 s.

2 FactRetriever.com | Interesting Facts for the Curious Mind. www.randomhistory.com.

3 Anto lo gia miro vo i de tsko i lite ra tury. - M.: A va nta, 2009. - 509 c

4 De tska ia lite ra tura. - M.: A ka de mia, 2010. - 384 c.

5 Detska ia literatura Avstrii, Germanii, Sveisa rii. Uchebna ia hrestomatia dlA nachalno $i$ i sredne $i$ skol. Chast 1. - M.: Vlados, 2011. - 384 c

6 Antipo va I.A. Kartina mira v obrazo vatelno i literature XVIII v. DlA dete i // De tski sbornik: Stati po de tsko i lite ra ture i antro po lo gii de tstva. - M.: 2003. 147-154 s.

7 A tarova K.N. Sekrety pro sto ty// Da niel Defo. Ro binzo n Kruzo. - M., 1990

8 Muravev V. Pute se stvie s Gulliverom. (1699-1970). - M.: Kniga, 1972. - 207 s

9 Bo iko S.P. Volse bna ia stra na Pera i SarlA Perro. M., 2002

10 SivAn T.V. K se mantike prostra nstve nny h ele me nto v v volse bno i skazke // Tipo lo giche skie issle do va nia po folkloru: Sb. sta te $i$. M., 1975

11 Sevchenko G.A. Predislovie // BratA Grimm/G. Gerstner; Per. s nem. E.A. Sensina. - M.: Mol.gvardia, 1980.-

12 Ko neva E. A. Pa rado ksy ska zo chno go tvo rche stva bra te v Grimm // Mo lo do i uche nyi. - 2016. - №28.

13 Bent M.I. Ne me ska ia ro ma nticheska ia no vella. Ge nezis, evolusia, tipolo gia Te kst. / M.I. Bent. - Irkutsk: Izda te lstvo Irkutsko go unive rsite ta, 1987. $119 \mathrm{~s}$

14 Suho mlinski, V.A. Serdse otda iu detAm / V. A. Suho mlinski. - 4-e izd. - Kiev: "RadAnska skola”, 1973. $356 s$.

МРНТИ 17.81.31

https://doi.org/10.51889/2021-1.1728-7804.49

\author{
Seitenova A., ${ }^{1}$ Bolatova . $^{2}$ \\ ${ }^{1,2}$ Al-Farabi Kazakh National University, \\ Almaty, Kazakhstan
}

\title{
CONCEPTUAL SIGNIFICANCE OF THE ARRAY OF COLOURS IN A WORK OF FICTION
}

\section{Abstract}

Based on the novels of Sherkhan Murtaza - "The Moon and Aisha", "The Red Arrow", "War with no Weapons", and "A Black Pearl", the article discusses the concept-forming significance of the nature of colors in the narrative system. In the course of the analysis, the emotional, psychological, philosophical, and mythological foundations of 
colors in portraying the hero's spiritual world, the author's ideas, and historical reality are being comprehended. The analysis was carried out on the basis of textual and typological systemic functional techniKues. The research results reveal multifold prospects of the concept-forming potential of the array of colors in a semiotic aspect. The psychological and ideological conceptual significance of the color array in the piece of work was contemplated within the framework of the literary poetic style of Sherkhan Murtaza.

Keywords: literature, poetic style, novel, literary landscape, array of colors, concept

\author{
Сейтенова А.Е., ${ }^{1}$ Болатова Г.Ж. ${ }^{2}$ \\ ${ }^{1,2}$ Әл-Фараби атындавы Қазақ ұлттық университеті, \\ Алматы, Қазақстан
}

\title{
КӨРКЕМ ШЫҒАРМАДАҒЫ ТУСТЕР ПАЛИТРАСЫНЫН КОНЦЕПТУАЛДЫ МӘНІ
}

\author{
Аң̧датпа
}

Мақалада Шерхан Мұртазаның “Ай мен Айша”, “Қызыл жебе”, “Мылтықсыз майдан”, “Қара маржан” романдары негізінде баяндау жүйесіндегі түстер сипатының концепт түзушілік мәні қарастырылды. Талдаулар барысында түстердің кейіпкер рухани әлемін, автор идеясын, дәуір шындығын бейнелеудегі эмоционалды , психологиялық, философиялық, мифологиялық негіздері зерделенді. Талдау жұмыстары текстологиялық, типологиялық, лингопоэтикалық жүйелі функционалды әдістер негізінде жүзеге асырылды. Зерттеу нәтижелері түстер палитрасының концепт түзушілік әлеуетін семиотикалық ыңғайда қарастырудың жан-жақты перспективаларын ашады. Ш.Мұртазаның қаламгерлік поэтика шеңберінде шығармадағы түстер палитрасының идеялық-психологиялық концептуалды мәні зерделенді. Талдау нәтижелері осы мәселеге қатысты ғылыми танымда тұжырымдалған белсенді түстер гаммасының философиялық эстетикалық мағынасын растайды. Мысалы ақ “пәк, бейбіт”, қара “қасірет, зұлымдық”, “қызыл шайқас, әділетсіздік”, сұр «қатер, құрбандық, суықтық” сынды түстер семантикасы нақты мысалдар негізінде дәйектелді. Осы негізде жеке шығармашылық поэтикадағы өмір, майдан, өлім ұғымдарымен сабақтас негізгі концептілердің түстер палитрасы арқылы жасалу жолы айқындалды.

Түйін сөздер: әдебиет, поэтика, роман, көркем пейзаж, түстер палитрасы, концепт

\author{
Сейтенова А.Е., ${ }^{1}$ Болатова Г.Ж. ${ }^{2}$ \\ ${ }^{1,2}$ Казахский нацииональный университет им.Аль-Фараби, \\ Алматы, Казахстан
}

\section{КОНЦЕПТУАЛЬНОЕ ЗНАЧЕНИЕ ПАЛИТРЫ ЦВЕТОМ В ХУДОЖЕСТВЕННОМ ПРОИЗВЕДЕНИИ}

\begin{abstract}
Аннотация
В статье на основании романов Шерхана Муртазы “Ай мен Айша”, “Қызыл жебе”, “Мылтықсыз майдан”, “Қара маржан” рассматривается концептообразующее значение характера цветов системы повествования. В ходе анализа были осмыслены эмоциональные, психологические, философские, мифологические основы цветов в изображении духовного мира героя, идеи автора, исторической действительности. Анализ был осуществлен на основе текстологических, типологических системных функциональных методик. Результаты исследования раскрывают всесторонние перспективы концептообразующего потенциала палитры цветов в семиотическом аспекте. В рамках литературной поэтики Шерхана Муртазы было осмыслено идейно-психологическое концептуальное значение палитры цветов в произведении. Результаты анализа подтверждают философское эстетическое значение активной цветовой гаммы, сформулированной с научной точки зрения в отношении данного вопроса. На конкретных примерах обоснована семантика таких цветов, как белый “мирный”, черный “зло”, красный “битва, несправедливость”, серый “угроза, жертва, холод”.
\end{abstract}

Ключевые слова: литература, поэтика, роман, художественный пейзаж, палитра цветов, концепт

Introduction. The artistic image of nature does not always play the role of a literary background in the work. Undoubtedly, the literary and artistic landscape has a spiritual and philosophical significance in accordance with the author's vision. While V. Khalizev noted that in the centuries-old culture of mankind there is "a deep and unbreakable continuity" of man and nature [1], Yu. Lotman emphasizes that the landscape macrocosm is metaphorically connected with man and nature microcosm [2]. In taking forward these ideas, M. Epstein considers each landscape as a large-scale metaphor and states that "the philosophy of nature is its relation to the person" as a clear principle [3].

It is known that the emphasis on the description of the beauty of nature in the art of speech dates back to antiKuity. Because the image of the mysterious nature is one of the main artistic tools that allow a person to express his views 
about himself and the world around him. In his works, Sh. Murtaza opens the way to look into the depths of the human soul through the artistic landscape. The writer expresses the image of nature, on the basis of which he assesses the attitude of the characters to it, thereby revealing their spiritual nature more deeply. The conceptual semantic of the landscape means the most objective depiction of the inner state of the protagonist. In many cases, the level of completeness of individual's personality is undoubtedly determined by his naturality. For example, the silent relationship of Aisha and Barshan with the Moon in the novel "The Moon and Aisha" is an important component that reveal the inner feelings of the protagonists in the context of life, personal destiny or chance. Similarly, Nariman, the protagonist of the novel "A Black Pearl", becomes a victim of injustice and betrayal, and seeks comfort in a crucial moment when his fate is being discussed. At this moment, he tries to imagine a bright picture and thinks of summer: "Even if it is winter now, it seems like summer. It is time to mow the hay. The summer rainstorm is over. The rainstorm is probably a tear of nature. It is a pleasure to cry. It was as if a mountain covered with juniper in the distancewas near. It was as if the cumulus clouds that fell on the hill after the rain kissed the mountain..." [4]. The beautiful image of nature, close to the idyll in the imagination of the protagonist, helps him to withstand the vulnerabilities of the surrounding human society, to find a cure for his soul. Such a landscape was usually used to depict the landscape and the character's direct or indirect meditative psychological state (emotional thought).

Living in harmony with nature in general is the main personality trait that testifies to the spiritual strength of the protagonist. For example, Aisha reveals the personality of Divine, believing soul in terms of her proximity to the moon. Among the landscape descriptions in the novel, the moon landscape has a special place.

Methods. The article uses historical, comparative, textual, system-functional and hermeneutic methods of research. The basis was taken from the memoir novels "The Moon and Aisha" (1995), "War with no Weapons" (1969), which tells about the hard work of working-class people during the Great Patriotic War, "A Black Pearl” (1976; State Prize of the Republic of Kazakhstan, 1978) describing the development of domestic production and environmental issues, and the novel "The Red Arrow" (1980-1984), which studies the life of T. Ryskulov. On the example of the above-mentioned works the nature of artistic psychology characteristic of Sherkhan Murtaza's writing is analyzed. In this regard, artistic psychology and its components are the subject of research. The works of the following scientists were used on the problems of artistic poetics and creativity of Sh. Murtaza: A.Veselovsky, M.Khrapchenko, V.Khalizev, Yu. Lotman, M. Karataev, Z.Kabdolov, S. Ashimbaev, M. Kopbayeva, T.Mameseit, etc. In this regard, the works of V. Kompaneets, M. Arnaudov, Ye. Basin, V. Belyanin, A. Esin, L. Ginzburg, B.Galanov, A.Temirbolat, B.Maitanov, G. Pirali, A. Kaliyeva, etc., which formed the theoretical and methodological basis of the dissertation work, are the main works. Researches of such scientists as Yu. Borev, V.Bogdanov, M.Andronikova, V.Savelyeva, Ye. Paderina were also used in the analysis.

Discussion. Color palette. The combination of colors in the relief of nature, the uniKue taste of the author in this selection will not be ignored. This, ultimately, means an artistic attempt at the most accurate expression of emotions in the study of reality. "For a great artist, the artistic text is not a reed blanket made of different pieces, it is a combination of diversity," says A. Bragina [5]. Therefore, every detail included in the space of a literary text carries with it a philosophical meaning, an aesthetic sense. From the novel "A Black Pearl" by Sh. Murtaza it is possible to assess the semantic meaning of the game of colors with such a symbolic background. The role of white color is special for a writer. The likeness of the Alatau to the white belt, and the clouds in the sky to the white caravan, the significance of the white strong storm in the destiny of Nariman, Marziya's seeing the white doves on the table and interpreting it for good, etc., the artistic details in the structure of the work serve to reflect positive emotions and bright thoughts about a bright future. G. Orazgaliyeva, studying the symbolic meaning of colors in the novel "A Black Pearl” by Sh. Murtaza, focuses on the mental meaning of white color in the Kazakh national worldview [6]. The peculiarities of the Turkic people's worldview and aesthetic sense of reality are shown by their significant weight on certain types of colors and their transformation into traditions. These are Kualities that are closely connected with the features of mental nature, such as folklore and mythopoetic worldview, formed over many centuries. Among the colors, white and black have a great philosophical and aesthetic significance for the Kazakh people. Depending on how they are used, they can have both positive and negative Kualities. For example, while black has a negative meaning in many nations, it is a sacred concept that has a very sacred meaning for the Kazakh people. White, red and black colors are the classic trio in the color palette [7]. In general, these colors have a high potential to convey philosophical and ideological meaning.

Describing the grave of a sick German child Elsa in "The Moon and Aisha", a symbolic and philosophical thought is marked by white, black and red colors: “... Elsa was buried not in the cemetery, but below in the hearth of the Berdimbet gorge. The hill was as dark as a red ant's nest in the middle of the white snow. It is like a lump on the surface of the white world. In general, the so-called "white world" would not be good for the whole world, if it were not for a secluded village like this stepchild. The surface of the whole world is clear. Covered in blood" [8].

The author describes the burial of the young man in the author's report with the phrase "buried". This false sign of a short-lived soul has become a small hill that looks like "a thousand moles". The author tells about the meaning of a short life, the reality of the time between death and life in general. Undoubtedly, the artist, who did not paint the appearance of the world in white color, associated it with the cruelty and bloodshed of human society ("The surface of the whole world is clear. Covered in blood"). It is safe to say that the most commonly used color in the image of color is white. It also has a scientific basis. I. Newton once proved that the origin of all other colors in the color spectrum is white. White color symbolized a sacred and wonderful phenomenon in the beliefs of the ancient Turks. For example, 
most of the remarkable characters in Turkic knowledge are associated with this color: white wolf, white leopard, white snake, white sheep, white horse, white feather, swan, etc. [9]. The complex semantic use of white color can be seen in the novel "War with no Weapons": "Both the land and the mountains are white. It seems that only wild rock is not covered with snow. For a moment, people seem to live like these peaks, one is high, other is low, do not change and live forever. The stability of the mountains would be terrifying for man" [10]. Once again, a contrasting image of black and white is drawn in front of our eyes. However, the dominant position of white color in the perception of the work seems to be psychologically comforting. The stormy landscape and the comparative differentiation of nature and human life, which create a certain space in the mind, lead to the idea of involuntary life and death. Anyway, this landscape painting is an indirect reference to the death of Orak on the front. This natural landscape, explored through the eyes of old man Mamai, seems to convey a cold message with its white color. The old man is really impressed. This is a surprise for Totia, who has been married for only a few months and has not yet tasted the sweets of youth and love. At least he does not understand anything:

“... Totia, who did not understand what was happening, dropped the bucket of milk after a while..

Fresh white steam came out and rolled towards the threshold. It poured out as if it was blocking the front door from blemish" [11]. The state of Totia, who has not yet tasted the bitter taste of lies, is reflected in the spilling of a bucket of milk. Sacred white milk stumbles across the threshold, as if wishing to prevent the sad news of the martyrdom of the elder son of old man Mamai and old woman Arai, Totia's beloved Orak. And the law of life is strict. Death is real. It is impossible to get rid of it. After all, white milk in this case symbolizes the good mood, honesty and hope of Totia. The plot of the death of Orak continues with a description of the landscape, which is based on another white color: "The sun rose in a snow-white reflection. The mountains seem to be swaying, like the shadows of people crying when they see each other" [12]. In this case, the white color became the basis of the psychological landscape, which gives another cold energy. The landscape, which should be logically perfect, is reminiscent of the harsh laws of life. Orak became a hero and died for the country and the land, and this false life goes on ...

"Understanding the artistic chronotope is achieved by understanding aspects such as color palette and fullness of sound. Because these characteristics are very important in the process of perception and understanding. The color of the space in which the characters live is based on information about their spiritual state. Therefore, by studying the colors and palette of the work, it is possible to predict the emotional feelings of the characters, changes in their mood - says A. Temirbolat. The color palette used in the work reveals the peculiarities of the author's inner world, his actions and attitude to the events. Color allows you to immerse yourself in the psychology of the narrator" [13]. The painting, based on the gray color and the sound of moaning in the novel "The Moon and Aisha", conveys an uncomfortable, frightening psychological atmosphere: "It was a cold gray cloud-covered autumn. I drive the horse onto the slope, scatter it across the barley's devotions, and bending over the yearling, walk along the country road from the station, and look at this bleak world. Below, on the other side of the river Teris, trains pass by. The faint sound of the locomotive is heard. As if the moan of locomotive could be heard louder when going west. Later, it turns out that those trains were going west for the war" [14]. The associatively chosen palette is rooted in the historical time of the novel - the psychology of war. The author's use of words that express discomfort in the inner world and the subjective approach to the world around him, demonstrates a masterful example of creating a convincing image of the combination of color and sound. The color palette is important in depicting the influence of the psychology of the character of any phenomenon around.

The visit of the bride of the aggressive volost in "The Red Arrow" is depicted against the background of a landscape full of psychologically frightening emotions. The frightening landscape of "dark clouds in the sky," "the cold November winds and swaying pines" is a harbinger of psychological traits such as bloodshed, murder, and revenge.

B. Maitanov, analyzing the voluminous novel of Sh. Murtaza about Turar Ryskulov, said: "In the works of nature sculpted by the writer, there are not analytical, but synthetic psychologism. But they have dynamic Kualities, adding subjective and meditative melodies to the narrative breath" [15].

In the climax of the events that formed the basis of the plot line in "The Red Arrow", natural phenomena are distinguished by the use of poetic words that depict the fate of the protagonist Ryskul. For example, in the psychological context of a "fluffy sparrow" that landed on a weak branch in the wind seems to refer to Ryskul. In difficult fateful turns, unable to realize all the devotion of his soul, the inner soul of Ryskul constantly finds expression in the manifestations of nature. "... Various types of "silent" landscape take part in differentiating the philosophical problems of life in the novel".

In general, "the problem of color perception is relevant in psychology" [16]. Color perception also depends on a person's mood in real time. This process is based on the aesthetic, ideological pursuits of the subject in the recognition of the world picture. Undoubtedly, there are moments in a work of art when processes and phenomena occuring in the environment as a result of the influence of socio-ideological, artistic and aesthetic factors are recognized by a particularly subjective point of view. The following three-dimensional passage is a clear example of the use of color schemes in a symbolic sense. In the novel "The Moon and Aisha", which describes the journey of Barskhan and his mother Aisha to the mill, the continuity of the psychology of the landscape and characters is manifested in a different character: "The blood-red pus in the sky is gradually softening and pink silk handkerchiefs fluttering. Seeing the long and short arrows of Boraldai, my voice cracked in surprise.

-What? - Aisha said, turned to me.

I snapped my fingers: 
- Sta-a-alin, - I said.

- Oh my God! - Aisha grabbed him by the collar.

After a while, the image of Stalin was distorted and the clouds parted.

Gradually, however, deer and calves began to appear. They run fast. Then Big Bad Wolf appeared.

I don't understand, I think I am the wolf. Thought the dream, but I was walking on the donkey holding grab the bottom of the bag over the donkey. I swear to God, it was me! But it is also true that I was walking with Aisha, holding the bag on this donkey.

I am the wolf and I am me! I am the both but separate. I am walking on the land and chasing deer in the sky. I was confused. I don't even know how we got home. As I entered the house, I turned around and saw gray wolf barking on the site of the destroyed old house of Shongar.

- Why are you standing? - said Aisha. - Help me lift the bag!

I don't remember the rest. I was unconscious for three days" [17].

The episodic scene, told in some mystical context, can be interpreted in different cognitive ways. The idea of the future of the nation was reflected in the perspective of the future of the Soviet period, which began with the cult of Big Bad Wolf in the historical time of the Turkic era and was founded by a bloody massacre. It is obvious that the characteristic features of the picture, such as "blood-red pus" and "pink silk handkerchiefs", also symbolize Soviet ideology. In the picture of a moving cloud, Barskhan and Aisha suddenly see the image of the leader Stalin. The appearance of a deer and Big Bad Wolf, torn apart and replaced by a calf, is a symbol of a bright future child. In this case, the psychological condition of Barskhan, who is riding a donkey, is interesting. It seems to him that his image has split in two. In any case, the above passage reveals the character's special Kualities of perception of the world and sense of the surrounding world. It is most likely a hint to the writer's future child.

Barskhan always tries to recognize his character from the type of mountain. In this way, he looks into the depths of his soul at this time. Once he said:

"Even though we climbed the Karatau ridge, Tanirtau is still high. I did not notice it when I was walking near, because it was stretched out far, elegant, too proud, too arrogant. I remembered Aisha's song:

\section{Tanirtau, I will come back to you, \\ I would never hunt your saigas. \\ At sixteen I became high spirited \\ Where am I to suffer now?" [18]}

The ambiguous landscape is traditionally based on the author's attempt to explore human nature through the image of nature. We do not always appreciate the good in others. The author considers the arrogant character of Tanirtau as a sign of cold beauty. This is confirmed by Aisha's song with the image of a mountain. There is no psychological connection between the mountain and the protagonist. There is an acceptance of the harshness of the real world, based on the belief in objective reality. We see the same position in the novel "A Black Pearl". The author sees the image of Alatau dimly: The Alatau stretched and began to blur, as if immersed in an unknown world from the distant AksuZhabagly and Tulkubas. It looks as if a giant dragon is bending over and enters the hole" [19].

In general, the mountain mythologeme reflects the special connection between the sky and Earth in artistic creativity, so it is often perceived as a metaphor for the existence of the Supreme ideals and the existence of the divine.

In the works of Sh. Murtaza, the inner feelings of the protagonist are sometimes described through sound images. In this regard, the landscape paintings give the impression that the scene is revived. Obviously, this is primarily due to the personal psychological characteristics of the author in relation to the perception of the environment, the world.

In the "War with no Weapons", Aidai missed her father in the war and cried, her companion Nurperzent wants to get rid of this sad moment. But the steppe remains silent, as if listening to the sadness of Aidai. There is a figurative "dead silence": "But there is no such thing as suspicion. At least the grasshopper does not make noise. At least the crow does not caw. Even the sounds of a train are not heard from afar. There is no smoke from the train like a decoration hanging in the air. Only the clatter of the donkey's hooves. There is such a time of eternity in the fall. These days usually do not last long. Sometimes the music seemed to shake the field slowly. It was like a cradle" [20]. An artistic detail in the author's story, such as "no smoke from the train like a decoration hanging in the air", depicts the fact that time in the image of the steppe stopped for a moment, and the natural dynamic landscape became static [of course, in the character's perception]. Psychologically, this creates an uncomfortable situation for the protagonist, which embodies the emotions of inner tension and resentment.

Researsh result. The ideological and psychological conceptual meaning of the color palette in the work was studied in the framework of Sh. Murtaza's poetic. The results of the analysis confirm the philosophical and aesthetic meaning of the range of active colors formulated in scientific knowledge on this issue. For example, the semantics of colors such as white "purity, peace", black "suffering, evil", "bloody battle, injustice", gray "threat, sacrifice, cold" were substantiated on the basis of concrete examples. On this basis the way of creation of the main concepts, connected with the concepts of life, war, death in the individual creative poetics through the color palette was determined.

Conclusion. From the above analysis we can see that in the work of Sh. Murtaza special attention was paid to the depiction of the spiritual world of the protagonist in competition with natural processes. Images of nature, 
manifestations of animal life, born of the desire to explore their surroundings, express a different worldview of a particular character, his ability to perceive the world.

Psychological parallelism, which has its origins in the ancient folklore heritage, has reached the present day, taking on new features in the process of literary development and changing artistically. Each writer contributes to this process with his own style.

In the process of creating a psychological landscape, it became possible to distinguish a number of stylistic and poetic features that are characteristic of the creative mind of Sh. Murtaza. On specific analysis we found that the writer pays special attention to night landscapes, including lunar landscapes. The next step in the recognition of the world picture is the mountain landscapes, depending on the spiritual and aesthetic tastes of the author. According to author's personal artistic position on the beauty of nature, the image of high mountains in the works of Sh. Murtaza not only plays the role of an artistic background. In the process of psychological comparison, they have the ability to highlight the heights and milestones of the inner spiritual life, mood and emotional processes of the character as a cardiological diagram. The author, who is not indifferent to the life of all living beings in nature, formulates an inseparable unity with nature, the dialectic of the soul through deep and thoughtful psychological landscapes.

References:

1 Khalizev V. Theory of literature // Textbook. High school.[ Teoriya literatury // Uchebnik. Srednyaya shkola] Moscow, 2005 -- $405 p$

2 Lotman Yu. On poets and poetry [O poetakh i poezii]// Art-SPb. - St. Petersburg, 1999 -- 848 p. - book

3 Epstein M. "Nature, the world, the secret of the universe ...": The system of landscape images in Russian poetry. High school.[ "Priroda, mir, tayna mirozdaniya ...»: Sistema peyzazhnykh obrazov v russkoy poezii. Srednyaya shkola.] - Moscow, 1990 -- 304 p.

4 Murtaza Sh. A Black Pearl. Novel // Compilation of writings in six volumes[Chernaya zhemchuzhina. Roman // Sobraniye sochineniy v shesti tomakh] - Volume 3. Novels, stories - Almaty: Kazygurt, 2002 -- 113 p.- article

5 Bragina A. Language vocabulary and culture of the country. Russian language [Yazykovaya leksika i kul'tura strany. russkiy yazyk]-Moscow, 1986 -- 152 p.

6 Orazgalieva $G$. Sherkhan Murtazaev's color palette // Actual scientific research in the modern world: collection of materials of international scientific conference. [Tsvetovaya palitra Sharekhana Murtazayeva // Aktual'nyye nauchnyye issledovaniya $v$ sovremennom mire: sbornik materialov mezhdunarodnoy nauchnoy konferentsii.]- Moscow, 2017 -- 276-281 p.

7 Shainova G. Symbolism of color in the novel "Throne of Satan” by R. Seisenbayev [Simvolika tsveta v romane R. Seysenbayeva «Prestol Satany».] // Bulletin: KazNU. Philological series. No. 6 - 2007. - 49-52 p. .- article

8 Murtaza Sh. Compilation of writings in six volumes[Sobraniye sochineniy v shesti tomakh] - Volume 5. The Moon and Aisha. Novel. - Almaty: Kazyurt, 2002 .-- 456 p

9 Maytanov B. Kazirgi Kazakh prosyndagy zamandas beinesi. - Almaty: Gylym, 1982 .-- 41 p.

10 Murtaza Sh. War with no Weapons. Novel. // Compilation of writings in six volumes[Voyna bez oruzhiya. Roman. // Sobraniye sochineniy v shesti tomakh ] - Volume 3. Novels, stories - Almaty: Kazyurt, 2002 .-- 73 p.

11 Murtaza Sh. War with no Weapons. Novel. // Compilation of writings in six volumes [Voyna bez oruzhiya.

Roman. // Sobraniye sochineniy v shesti tomakh] - Volume 3. Novels, stories - Almaty: Kazyurt, 2002 .-- 87 p.

12 Murtaza Sh. War with no Weapons. Novel. Compilation of writings in six volumes [Voyna bez oruzhiya.

Roman. // Sobraniye sochineniy v shesti tomakh]-Volume 3. Novels, stories - Almaty: Kazyurt, 2002 .-- 98 p.

13 Temirbolat A. Categories of chronotope and temporal rhythm in literature. Monograph.[ Kategorii khronotopa i temporal'nogo ritma v literature. Monografiya] - Almaty: Securities, 2009. - 504 p

14 Murtaza Sh. Compilation of writings in six volumes [Sobraniye sochineniy v shesti tomakh]-Volume 5. The Moon and Aisha. Novel. - Almaty: Kazyurt, 2002 .-- 128 p.

15 Maytanov B. Artistic semantics of landscape [Khudozhestvennaya semantika peyzazha]- Almaty: Kazakh University, 2010 .-- $108 \mathrm{p}$.

16 Osgud Ch., Susi J., Tannenbaum P. Application of the Semantic Differential Methodology to Research on Aesthetics and Related Problems // Semiotics and Art Metrics. - Moscow: Mir, 1972 .-- 251 p.

17 Murtaza Sh. Compilation of writings in six volumes[Sobraniye sochineniy v shesti tomakh] - Volume 5. The Moon and Aisha. Novel. - Almaty: Kazyurt, 2002 .-- 111 p.

18 Murtaza Sh. Compilation of writings in six volumes [Sobraniye sochineniy v shesti tomakh]-Volume 5. The Moon and Aisha. Novel. - Almaty: Kazyurt, 2002 .-- 118 p.

19 Murtaza Sh. Compilation of writings in six volumes [Sobraniye sochineniy v shesti tomakh]-Volume 5. The

Moon and Aisha. Novel. - Almaty: Kazyurt, 2002 .-- 36 p.

20 Murtaza Sh. War with no Weapons. Novel // Compilation of writings in six volumes[Voyna bez oruzhiya. Roman. // Sobraniye sochineniy v shesti tomakh] - Volume 3. Novels, stories - Almaty: Kazyurt, 2002 .-- 101 p. 